\author{
ANNA SCHMIDT \\ Uniwersytet im. Adama Mickiewicza \\ w Poznaniu
}

\title{
CHILD FROM SINGLE PARENT FAMILY IN PRESCHOOL ENVIRONMENT - A THEORETICAL OUTLINE AND PRACTICAL TIPS ${ }^{1}$
}

\begin{abstract}
Schmidt Anna, Child from Single Parent Family in Preschool Environment - a Theoretical Outline and Practical Tips [Dziecko z rodziny niepełnej w środowisku przedszkolnym - zarys teoretyczny i wskazówki praktyczne]. Studia Edukacyjne nr 44, 2017, Poznań 2017, pp. 363-375. Adam Mickiewicz University Press. ISSN 1233-6688. DOI: 10.14746/se.2017.44.22

Nowadays, the subject of a family is often mentioned and researched. It's needs, transformations, crisis, roles and functioning are widely discussed. It is indeed a very complex issue. The article present the theoretical background and mention diverse sources concerning issues such as: single families, preschool environment, child development, single parenting - definitions and models, pre-school environment, child development, challenges and support for a child from single parent family in a kindergarten. The great role of teacher-educator and other specialists, but also working with institutions in the process of supporting the family. In the text the organization of comprehensive assistance for the child was also highlighted. In conclusion, the author referred to the results of her mini-resources and pointed to the need to support the child in the area of emotional and social functioning, which in case of children from single parent family is particularly vulnerable and shaky.
\end{abstract}

Key words: family, single parent family, families models, child development, preschool environment, support

\section{Introduction}

"A family home is usually the place where the traumas accumulated during the day are discharged. It is a place of cleansing, where you can afford more than outside the house..." A. Kępiński. It is an oasis of calm, a place of rest, love, where you feel safe and free. However, the fundaments of the house are not the walls nor the building, but the people who live in it and create the family

${ }^{1}$ An article based on the author's master thesis, entitled: The functioning of a child from a part-time family in a pre-school environment, written under the supervision of prof. dr hab. Alexander Zandecki. 
together. They play a very important role in the lives of every person, especially the one who, from an early age, gains new skills, competences and knowledge about the world around him/her. He or she learns to function in society, abide by specific norms and principles, shapes personality and values. The family determines the life of a human being, while at the same time being the basis of the functioning of societies and, consequently, the entire population. On many occasions in the media or in politics, its importance is emphasized, but at times it may seem that its needs, difficulties and threats are pushed to the background. One of them is certainly the growing number of divorces, as well as families broken up and incomplete. This phenomenon has a huge impact on the functioning of all its members, but especially dangerous seems to be for the youngest of them - children.

Therefore, in this article I have focused on the incomplete family, because its image in modern society is becoming more and more common, as is confirmed by numerous studies and my own observations. I have analyzed the functioning of a child from single parent family in a pre-school environment, which is particularly close to me, since it has also been my workplace, where I encounter everyday problems of the child and parents in the above-mentioned family model.

\section{The single parent family - definition and classification}

The term "single parent family" by many authors is used as opposed to the term "full family". M. Tyszkowa defines it as a family in which only one parent is involved in both: the household and the raising of children. ${ }^{2}$ Often, researchers use the term "decomposed family" 3 and distinguish two types of families: incomplete families (never complete families) and decomposed (their completeness has been decayed for various reasons, such as death, separation, or divorce). According to J. Stochmiałka, "the basic criterion for deciding a family to belong to a group of incomplete families is the single parenting of a child" ${ }^{4}$ A. Kwak defines a family through the prism of difficulties:

living one adult outside the family (dead, living separately) - common to all; experience by family members of breaking basic ties that connect them with an absent parent;

${ }^{2}$ M. Tyszkowa, 1974. Source: K. Walęcka-Matyja, Zachowania społeczne młodzieży a uwarunkowania rodzinne $i$ osobowościowe, Instytut Psychologii UŁ, p. 24, http://dspace.uni.lodz. pl/xmlui/bitstream/handle/11089/5039/K.Wal\%C4\%99cka-Matyja \%282009\%29.Zachowania $\% 20$ spo $\%$ C5\%82eczne $\% 20 \mathrm{~m} \%$ C5\%82odzie \% C5\% BCy\%20a\%20uwarunkowania\%20rodzinne\%20i\%20osobowo\% C5\%9Bciowe.pdf?sequence=1\&isAllowed=y, [dostęp: 01.05.2017].

${ }^{3}$ H. Stasiak, 1975; A. Szymanowska 2000. Source: K. Walęcka-Matyja, Zachowania społeczne młodzieży.

${ }^{4}$ J. Stochmialek, Geneza i następstwa funkcjonowania rodzin niepetnych, Auxilium Sociale, 2003, p. 10. 
(usually) self-running household by one parent; possible participation of children in more than one family (in the case of repeated / new parental marriages). ${ }^{5}$

This type of family in the modern world is increasingly popular and even universal. This can also be witnessed by the fact that new terms referring to the institution of single parenthood appear. ${ }^{6}$

As in the case of full families, also models of incomplete families can be distinguished for many aspects. In the fact of absence of one parent, T. Pilch distinguished among them:

- families orphaned by the death of one parent,

- families shattered by divorce or divorce,

- family of single, unmarried mothers with child,

- family incomplete time. ${ }^{7}$

E. Kozdrowicz presented the following typology:

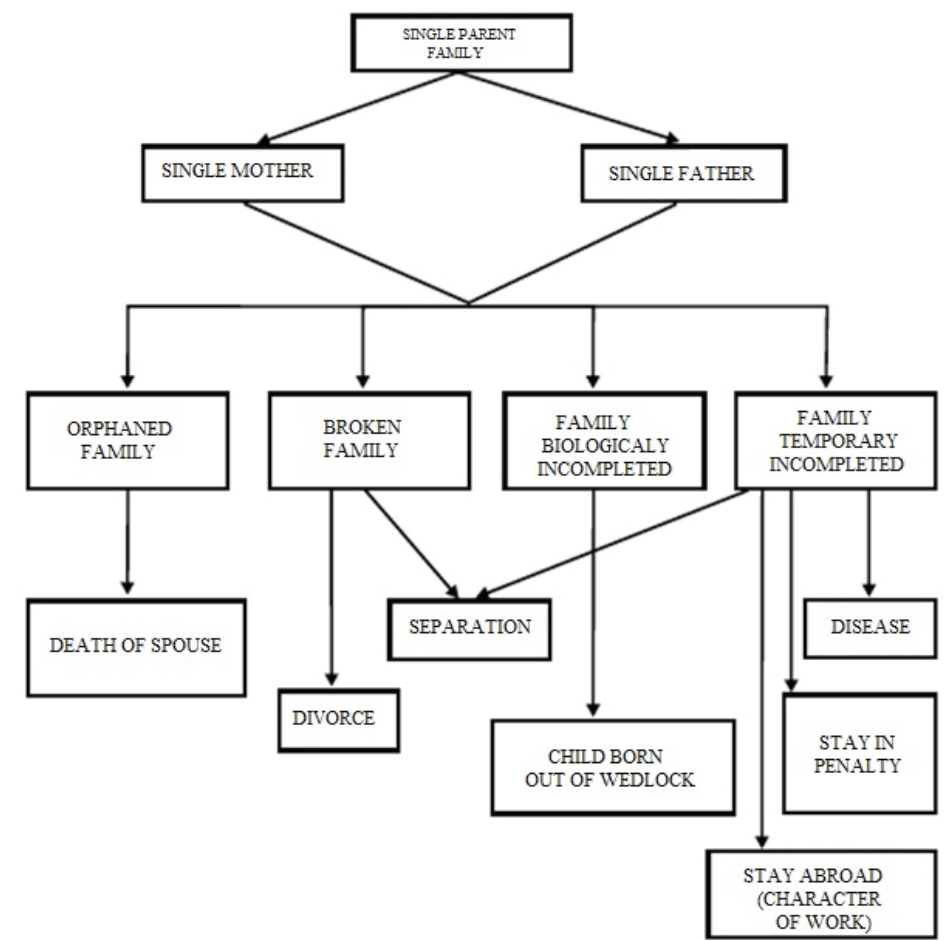

Fig. 1. Typology of incomplete families according to E. Kozdrowicza, taking into account the causes of their uprising

(Source: E. Kozdrowicz, The situation of a child in a single mother's family, Warszawa 1989)

${ }^{5}$ M. Racław, D. Trawkowska, Samotne rodzicielstwo. Między diagnoza a działaniem, Warszawa 2013, p. 9.

${ }^{6}$ E. Jurczyk-Romanowska, Samotne rodzicielstwo w systemie pomocowym państwa, [in:] Wychowanie w rodzinie. Wspótczesna rodzina w sytuacji zmiany, Jelenia Góra 2011, p. 252.

${ }^{7}$ T. Pilch, 1984, Source: K. Walęcka-Matyja, Zachowania społeczne młodzieży, p. 24. 
The scale of the phenomenon of single parenting is constantly increasing. According to the information published by the Central Statistical Office in Poland in the report titled Households and families. Demographic Characteristics:

In 2011, more than one in four families was created by a single parent with children. In 2002, the parents raising their own children were about 2030 thousand, while in 2011 by almost 473 thousand. (Over 23\%) more, almost 2503 thousand. ${ }^{8}$

That is why it is so important for teachers, educators and people working with young children to be aware of the situation of the modern family and its transformations in order to better understand the world in which children are present and to provide them with the best possible support.

\section{Preschool environment - outline characteristics}

To characterize the concept of "pre-school environment", it is impossible not to start by defining the "environment". H. Radlińska means environment as

a set of conditions, among which an individual exist and factors transforming the personality, interacting constantly or for a longer time. It is a complex of natural, cultural and personal phenomena. ${ }^{9}$

A similar definition is given by W. Okon, who considers that the environment consists of ecological, economic, political, social, cultural-educational and institutional processes, but also relationships and dependencies between them. It is a space that allows an individual to create, operate, and build conditions for his/her own functioning. ${ }^{10}$

M. Łobocki divided the environment into:

a) the natural environment: family, peer group;

b) intentional environment: kindergarten, school, orphanage. ${ }^{11}$

What the pre-school environment is? The new PWN Encyclopedia states that a kindergarten is a "care and education institution for children aged 3 years to begin compulsory schooling" ${ }^{12}$ However, in exceptional circumstances, children of 2.5 years of age may also be admitted to the kindergarten, and children who are 6 years old may stay longer in the institution, if they are deferred from compulsory schooling or have a psychological and pedagogic counseling appointment for special education. ${ }^{13}$

${ }^{8}$ Gospodarstwa domowe i rodziny. Charakterystyka demograficzna, Warszawa 2014, p. 44.

${ }^{9}$ H. Radlińska, Pedagogika społeczna, Warszawa 1961, p. 31.

${ }^{10}$ W. Okoń, Stownik pedagogiczny, Warszawa 1984, p. 306.

${ }^{11}$ M. Łobocki, ABC wychowania, Lublin 1999, p. 43-56.

${ }^{12}$ Encyklopedia Powszechna PWN, Warszawa 1998, p. 361.

${ }^{13}$ E. Kowar-Pogoń, Przedszkole - pierwsza instytucja edukacyjna w życiu dziecka, http:/ / biuletyn. kuratorium.krakow.pl/index.php?art_id=51\&menu_item=2\&numer=4, [dostęp: 01.05.2017]. 
The 2016 Central Statistical Office report states that in the school year 2015/2016 there were 21115 officially registered pre-primary education institutions in Poland, and the number of children attending them was 1140602 children. ${ }^{14}$ Today kindergarten for many children is a "second home". The place where they spend almost half of their day. After the family the most important development environment of the "little human". It is no wonder that more and more demands are placed on it as well as new goals and tasks.

Main goals of pre-school education formulated and published by the Polish Ministry of Education in the Regulation of the Minister of National Education of 17 June 2017 amending the regulation on the core curriculum of pre-school education and general education in particular types of schools. According to its content, the purposes of pre-school education are:

1) supporting children in developing aptitudes and shaping the intellectual activities they need in their day-to-day situation and further education;

2) building a system of values, including bringing up children so that they better know what is good and what is bad;

3) shaping in children the emotional resistance necessary for rational coping in new and difficult situations, including the mild worsening of stress and failure;

4) developing the social skills of children, which are essential in proper relationships with children and adults;

5) creating conditions conducive to common and consistent play and learning of children with diverse physical and intellectual capabilities;

6) caring for children's health and their physical fitness; encouraging participation in sports and games;

7) building children's knowledge of the social, natural and technical world and developing the ability to present their thoughts in a way that is understandable to others;

8) bringing children into the world of aesthetic values and developing speaking skills through music, dance, singing, small theatrical forms and fine arts;

9) shaping children's sense of social belonging (peer group, peer group and national community) and patriotic attitude;

10) providing children with better educational opportunities by fostering curiosity, activism and autonomy, and developing knowledge and skills which are important in school education;

11) developing children's reading skills and preparing children to acquire writing skills;

12) preparing children to use modern foreign languages by raising their linguistic awareness and cultural sensitivity, and building positive motivation to learn foreign languages at later stages of education;

13) in kindergartens enabling children belonging to national and ethnic minorities and a community using the regional language referred to in the Act of 6 January 2005 on National and Ethnic Minorities and Regional Language (Journal of Laws of 2015), maintaining and developing the sense of national, ethnic and linguistic identity -

${ }^{14}$ Oświata i wychowanie w roku szkolnym 2015/2016, Warszawa 2016, http:/ / stat.gov.pl/obszary-tematyczne/edukacja/edukacja/oswiata-i-wychowanie-w-roku-szkolnym-20152016,1,11. html, [dostęp: 01.05.2017]. 
preparing children to use the language of a national or ethnic minority or regional language by raising their national, ethnic and linguistic awareness, building positive motivation to learn the language of a national or ethnic minority or regional language at further stages of education". ${ }^{15}$

As well as offer individual support for the development of each child according to his or her abilities and needs. According to E. Kowar-Pogon: "The most important goal of pre-school education is the comprehensive development of the child's personality. Kindergarten is a place to prepare child to attend school. Kindergarten creates such educational and emotional conditions so that the child can fully develop in many areas: intellectual, emotional, cognitive and social. ${ }^{16}$

The goals mentioned earlier in some way determine and even impose certain functions of the preschool environment. We distinguish e.g. care and health function, stimulation function, prophylactic function, correctional function, compensatory function, didactic function and socialization function. ${ }^{17}$ Another classification was made by R. Więckowski, who distinguished:

- care and education function,

- development function,

- cognitive function. ${ }^{18}$

M. Burtowy, in her classification, gave the following functions of kindergarten:

- care function,

- educational function,

- didactic function,

- environmental function. ${ }^{19}$

These are just some of the pre-school functions that are integral part to their goals, and they all contribute to the proper development and functioning of a small child. Is worth remembering because

preschool age is the most important period in a person's life. (...) Everything that people learn in their childhood what they will assimilate to what they experience in this earliest period of their life will affect in their future life. The same or similar situations experienced at a later age will not so strongly affect certain personality traits such as those of childhood.

In addition, the mind of the child is absorbing, the cognitive ability are the biggest, so it is necessary to create the child optimal conditions for learning and development. It

${ }^{15}$ Rozporządzenie Ministra Edukacji Narodowej z 17 czerwca 2016 r., http:/ / www.dziennikustaw.gov.pl/du/2016/895/1, [dostęp: 01.05.2017].

${ }^{16}$ E. Kowar-Pogoń, Przedszkole - pierwsza instytucja.

${ }^{17}$ Ibidem.

${ }^{18}$ R. Więckowski, Wychowanie przedszkolne podstawowym etapem edukacji, Wychowanie w Przedszkolu, 1994, 9, p. 522.

${ }^{19}$ A. Brzezińska, M. Burtowy, Psychopedagogiczne problemy edukacji przedszkolnej, Poznań 1992, p. 39. 
is a task for experienced teachers and educators, who can diagnose the possibility and properly manage each child's development process to ensure the best possible start. ${ }^{20}$

Kindergarten is the first educational institution of the child. This is a place where children learn how to function in society, acquires new skills, acquires knowledge and discovers themselves and the great world around them. The tasks and challenges that a pre-school environment must face are not easy, but on the level of implementation and proper operation depends how well the child's development will be.

\section{Child from a single parent family as a preschooler}

\section{P. Kosiński writes in his article:}

The first need of man is love, the feeling of being loved. It's not about words, but about attitude. Man basically reads this attitude of others to himself. A little child feels good whether he is loved or happy for his parents, for his loved ones. The desire to take him in the arms, touching, showing others, bragging about the "treasure" is a sufficient signal of love. We can feel the sense the love or lack of it from the earliest moments of life.

Everyone needs acceptance, accept me as I am. Any kind of unacceptance (e.g. sex, time, circumstances of the birth of a child) can become a cause for suffering, and sense of threat. It is not easy for a child to live with the feeling that it causes disappointment that it causes suffering that causes anxiety in the loved ones.

The feeling of love, acceptance is something that is necessary for human development at every stage of life. ${ }^{21}$

The child from a single parent has to face with different challenges - child must meet the same requirements as the child from a full family, but often has a lot of bad experiences, as well as many emotional, social or cognitive deficits. The process of harmonious functioning determines, and often even disturbs. They usually include problems with acquiring knowledge, focusing attention, observing established norms and principles, establishing relationships with others, and expressing own thoughts and emotions, which is related to the often observed emotional lability or elevated level of anxiety and aggression. Statistics indicate that

children from single parent families are less likely fully accepted by peers and more likely isolated than six-year-olds children from full families. (...) The degree of inten-

${ }^{20}$ I. Smelka, Przedszkole pierwszym krokiem w rozwoju każdego dziecka, http://www.przedszkole139.krakinfo.pl/index.php?id=1102, [dostęp: 02.05.2017].

${ }^{21}$ P. Kosiński, Pierwsza potrzeba człowieka? Być kochanym!, http://www.deon.pl/inteligentne-zycie/psychologia-na-co-dzien/art,356, pierwsza-potrzeba-czlowieka-byc-kochanym.html, [dostęp: 02.05.2017]. 
sity of peer sympathy for the study children from incomplete families is lower, but the degree of intensity of antipathy is higher than that of children with complete family structures. In relation to six-year-olds raised by one parent, negative emotions are often reported, and positive emotions are observed in relation to the respondents from full families. ${ }^{22}$

The kindergarten environment have to become for a child from an single parent family an oasis of peace and security. A place where there is a nice, friendly atmosphere, where people are staying, where support is always counted. A shelter where you can feel "a small" person important and needed, whose rights are respected, which can count on help and support in their activities. In the end, kindergarten is the "second home" where children acquire new skills, competences, discover themselves and the world, shape their character, personality, and learn social norms and harmonious actions in the group. At this often overlooked institution there is a great responsibility for the development and functioning of the youngest, especially those who do not receive family support, equal opportunity and compensation, and to meet deficits so that they could have a common, equal start in a further adult life.

\section{Chosen problems of a child from single parent family in preschool environment}

As stated in the B. Krason's article: “The proper development of the child's psychological state is the need for both the mother and the father, because of the natural differences between women and men they meet the needs of the child" ${ }^{23}$ A child from a broken family in a preschool environment can face many problems.

The implications of the family incompleteness the impact of its organization on the individual members - the adult and the child - are highlighted in the reflection on family incomes. Although the Poles (Polish General Social Survey 2002) in a high percentage $(60 \%)$, the highest in Europe, agreed with the statement that "a single parent can raise children just as well as both parents", theoreticians and practitioners point to a number of difficulties associated with the process of socializing a child (children) in an incomplete family. Whatever the reason, the absence of an adult is considered as a distortion of the educational process. It is suggested that the child lose the model of one parent's role, which translates into future difficulties in building a proper relationship (...). ${ }^{24}$

${ }^{22}$ I. Zwierzchowska, Pozycja społeczna w grupie przedszkolnej dzieci z rodzin niepetnych, Bliżej Przedszkola. Wychowanie i Edukacja, 2007, 3, p. 27.

${ }^{23}$ B. Krasoń, Niepetna rodzina to niepetne wychowanie, http://www.deon.pl/inteligentne-zycie/wychowanie-dziecka/art,201,niepelna-rodzina-to-niepelne-wychowanie.html, [dostęp: 03.05.2017].

${ }^{24}$ M. Racław, D. Trawkowska, Samotne rodzicielstwo, p. 6. 
The most common problems encountered by a child in a preschool environment include:

1) Emotional defects affecting the normal functioning of the child in the environment and often cause deviant behavior.

2) Difficulties in adhering to certain norms and principles and acting as a preschooler.

3) Disorders in social development, abnormal relationships with peers or lack thereof.

4) Difficulties in the cognitive field - e.g. concentration problems, low level of memorization and assimilation of new knowledge.

5) Problems related to the material sphere - e.g. malnutrition, inappropriate clothing, or problems with maintaining proper hygiene. ${ }^{25}$

We have to remember that the list of difficulties is much longer and depends on the individual situation of the child and his/her family, so it is important to thoroughly diagnose it and to take action as soon as possible to improve their functioning and prevent new deficits and crises.

\section{The role of teacher - educators in the organization of forms of support and help}

The single parent family undoubtedly needs support and assistance in various areas of its functioning. Examples of such activities may include: childcare, financial help, mental support, help in overcoming difficulties, stimulating action and realizing dreams. People who first see the problems of a pre-school child and his family are certainly teachers, especially the educator, and other specialists such as psychologists, speech therapists and staff. They can recognize the difficult situation in which the incomplete family is, take steps to support it and not allow for a longer crisis.

According to E. Masłowska the definition of educator can be considered in two categories: narrower and wider. According to the author:

The narrower definition indicates that the educator is a teacher who is in a special relationship with the class (his role is a function). For educators of a class is given: greater time commitment; greater emotional involvement; and tasks related to: planning a class curriculum; implementing a parenting plan; responding to a variety of child-rearing phenomena in the classroom; intervention in specific cases; cooperation with parents; collaborate with other teachers in this classroom. ${ }^{26}$

${ }^{25}$ R. Szymańska, Niepowodzenia szkolne i zaburzenia w rozwoju społecznym uczniów w młodszym wieku szkolnym wywodzacych się z rodzin rozbitych, http://www.szkolapodstawowa18radom.republika.pl/przyklad11.htm, [dostęp: 03.05.2017].

${ }^{26}$ E. Masłowska, Nowe spojrzenie na wychowawce w szkole - rozwój zawodowy wychowawcy, http:/ / www.profesor.pl/publikacja,6944,Artykuly,Rozwoj-zawodowy-wychowawcy-nowe- 
Although the above analysis of the tasks and responsibilities of the teachers-teacher's shoulders emphasizes its functioning in the school environment, it also has the same reflection in the preschool environment.

Who is a pre-school teacher?

Educator is anyone who comes into direct contact with a human being in a situation where it can have a significant impact on the development of experience, and thus on the personality of the young person. ${ }^{27}$

The teacher is a very important person, whose role is not always appreciated by the public, but he is not only responsible for the proper functioning of the institution, but he cares about every individual, child, its functioning and the closest living environment. It is a person who undertakes a number of activities aimed at improving the living conditions and development of his patients. A. Okońska-Walkowicz distinguished the following categories of educator activities: supporting the individual needs of the student, building a positive atmosphere and interpersonal relationships within the group, implementing them for various social roles, planning, diagnosing educational problems and checking the effects of actions taken. ${ }^{28}$

A summary of all the actions that the teacher-educator undertakes and the responsibilities that lie on his shoulders, as well as the challenges that must be tackled, may be the words:

The teacher in his work should aim at developing the mental ability and personal interests of the students in the intellectual, mental, health, aesthetic and moral dimensions; to teach respect and tolerance to others, to prepare the students for the recognition of moral values, to shape the attitude of dialogue, the ability to listen to others, to understand their views. ${ }^{29}$

In a short but exact way they describe the issues that seem to be particularly important in teacher's - educator's work.

-spojrzenie-na-wychowawce-w-szkole-referat-na-rade-szkoleniowa-w-ramach-WDN, [dostęp: 03.05.2017].

${ }^{27}$ Ibidem.

${ }^{28}$ A. Okońska-Walkowicz, Nauczyciel wychowawca, https:/ / docs.google.com/viewer?a=v\&q =cache:YmMNMWNvtlgJ:www.nw.sto.org.pl/down/Anna_Okonska_WalkowiczNauczyciel_wychowawca.pdf + wychowawca + klasy+definicja\&hl=pl\&gl=pl\&pid=bl\&srcid=ADGEEShPsxO0zauVdeiacLBcMIEzuVI_FHv3zYNS8Ct8xHE8UXKDfSr4N_NPD0x7_RM6pfAyOR1bnDZMhfchk5i7EsL19ou39LxMKUwEAhb71Pbgcnm7JkhhH6OaVhE0OwHsUO7Ih\&sig=AHIEtbQR7z8Oe4d8m1XMi0iOOFlEgNzTwwww.nw.sto.org.pl/.../ Anna_Okonska_Walkowicz-Nauczyciel_wyc...., [dostęp: 03.05.2017].

${ }^{29}$ A. Nowak, Rola wychowawcy w edukacji uczniów - referat, Konin 2003, p. 7. Dostępny także w zasobach internetowych w formacie pdf: http:/ / webcache.googleusercontent.com/search?q=cache:o1ck1eT-A6cJ:www.sp9.1m.pl/Artykuly/Rola\%2520wychowawcy \%2520w\%2520edukacji \% 2520uczniow.pdf+A.+Nowak+Rola+wychowawcy+w+edukacji+uczni \% C3\% B$3 \mathrm{w} \& \mathrm{~cd}=1 \& \mathrm{hl}=\mathrm{pl} \& \mathrm{ct}=\mathrm{clnk} \& \mathrm{gl}=\mathrm{pl}$, [dostęp: 03.05.2017]. 
A psychologist, speech therapist, correctional gymnast, music, rhythm, or any other specialists - it is impossible to list all the people working in a pre-school facility, but the fact is that every adult working in this area should be alarmed with financial problems, the functioning of a child in a group, or a parent-child relationship, they should react by direct contact with the principal, teacher, educator, pedagogue, psychologist or other specialist to provide the child with the necessary support and assistance. Early diagnosis of the problem and difficulties, taking action to overcome them, gives the chance of proper, further development and avoidance many disorders or deficits.

\section{Conclusions and reflections}

The theme of functioning of a the child from a single parent family is very extensive. However, at the end, I would like to refer to my mini-research which I made by using the individual case method. The study group consisted of 10 pre-school children, who were monitored throughout the school year, as well as information on their functioning by conducting interviews and surveys among parents, teachers, staff members, and other professionals who contacted them, and also kept up with children's results, including in diagnoses, child-proof cards, work cards and any free items. I know that the research group which I analyzed was not very large, but the results I find out are very interesting. The study showed that the functioning of children from single parent family differs from this children from full family. The main difference is seen in the emotional and social sphere, and in the cognitive sphere children's development has been smooth or slightly disturbed. Of course, these conclusions are only a signal for further in-depth analysis of this topic, but at this stage we can conclude that the child from the incomplete family requires special support in terms of emotional development and social functioning. It is important that parents, teachers, educators and students who care for the young child in the future are aware of this fact. From a young age, we should give children a sense of security, belonging, and build a friendly and open environment for their needs and capabilities. The quickest diagnosis and intervention gives us the chance to work out new solutions and prevent deficits that have a huge impact on the harmonious functioning and development of baby from an early age. It is worthwhile to focus on family and pre-school environments to develop various forms of cooperation, as well as possible support paths from other institutions, which are extremely important and allow for the creation of a comprehensive offer of comprehensive support. Do not be indifferent, do not be afraid to act, because even the smallest step on our part, giving a helping hand, can become a milestone to change actuality and save the family. 


\section{BIBLIOGRAPHY}

Brzezińska A., Burtowy M., Psychopedagogiczne problemy edukacji przedszkolnej, Poznań 1992. Encyklopedia Powszechna PWN, Warszawa 1998.

Gospodarstwa domowe i rodziny. Charakterystyka demograficzna, GUS, Warszawa 2014.

Jurczyk-Romanowska E., Samotne rodzicielstwo w systemie pomocowym państwa, t. III/2011, Jelenia Góra 2011.

Kosiński P., Pierwsza potrzeba człowieka? Być kochanym!, http://www.deon.pl/inteligentne-zycie/psychologia-na-co-dzien/art,356, pierwsza-potrzeba-czlowieka-byc-kochanym.html, [dostęp: 02.05.2017].

Kozdrowicz E., Sytuacja dziecka w rodzinie matki samotnej, Warszawa 1989.

Kowar-Pogoń E., Przedszkole - pierwsza instytucja edukacyjna w życiu dziecka, http:// biuletyn.kuratorium.krakow.pl/index.php?art_id=51\&menu_item=2\&numer=4，[dostęp: 01.05.2017].

Krasoń B., Niepetna rodzina to niepetne wychowanie, http://www.deon.pl/inteligentne-zycie/wychowanie-dziecka/art,201,niepelna-rodzina-to-niepelne-wychowanie.html, [dostęp: 03.05.2017].

Łobocki M., ABC wychowania, Lublin 1999.

Masłowska E., Nowe spojrzenie na wychowawce w szkole - rozwój zawodowy wychowawcy, http:/ / www.profesor.pl/publikacja,6944,Artykuly,Rozwoj-zawodowy-wychowawcy-nowe-spojrzenie-na-wychowawce-w-szkole-referat-na-rade-szkoleniowa-w-ramach-WDN, [dostęp: 03.05.2017].

Nowak A., Rola wychowawcy w edukacji uczniów - referat, Konin 2003. Dostępny także $\mathrm{w}$ zasobach internetowych $\mathrm{w}$ formacie pdf: http://webcache.googleusercontent. com/search?q=cache:o1ck1eT-A6cJ:www.sp9.1m.pl/Artykuly / Rola\%2520wychowawcy \% 2520w \% 2520edukacji\% 2520uczniow.pdf+A.+Nowak+Rola+wychowaw$c y+w+$ edukacji+uczni\% C3\%B3w\&cd=1\&hl=pl\&ct=clnk\&gl=pl, [dostęp: 03.05.2017].

Okoń W., Stownik pedagogiczny, Warszawa 1984.

Okońska-Walkowicz A., Nauczyciel wychowawca, https://docs.google.com/viewer?a=v\&q =cache:YmMNMWNvtlgJ:www.nw.sto.org.pl/down/Anna_Okonska_WalkowiczNauczyciel_wychowawca.pdf+wychowawca+klasy+definicja\&hl=pl\&$\mathrm{gl}=$ pl\&pid=bl\&srcid=ADGEEShPsxO0zauVdeiacLBcMIEzuVI_FHv3zYNS8Ct8xHE8UXKDfSr4N_NPD0x7_RM6pfAyOR1bnDZMhfchk5i7EsL19ou39LxMKUwEAhb7lPbgcnm7JkhhH6OaVhE0OwHsUO7Ih\&sig=AHIEtbQR7z8Oe4d8m1XMi0iOOFlEgNzTwwww.nw.sto.org.pl/.../Anna_Okonska_Walkowicz-Nauczyciel_wyc...., [dostęp: 03.05.2017].

Oświata i wychowanie w roku szkolnym 2015/2016, GUS, Warszawa 2016, http://stat.gov. $\mathrm{pl} /$ obszary-tematyczne/edukacja/edukacja/oswiata-i-wychowanie-w-roku-szkolnym-20152016,1,11.html, [dostęp: 01.05.2017].

Racław M., Trawkowska D., Samotne rodzicielstwo. Między diagnoza a działaniem, Warszawa 2013.

Radlińska H., Pedagogika społeczna, Warszawa 1961.

Rozporządzenie Ministra Edukacji Narodowej z 17 czerwca 2016 r., http:/ / www.dziennikustaw.gov.pl/du/2016/895/1, [dostęp: 01.05.2017].

Smelka I., Przedszkole pierwszym krokiem w rozwoju każdego dziecka, http:/ / www.przedszkole139.krakinfo.pl/index.php?id=1102, [dostęp: 02.05.2017].

Stochmialek J., Geneza i następstwa funkcjonowania rodzin niepetnych, Auxilium Sociale, 2003.

Szlendak T., Socjologia rodziny. Ewolucja, historia, zróżnicowanie, Warszawa 2011. 
Szymańska R., Niepowodzenia szkolne i zaburzenia w rozwoju społecznym uczniów w młodszym wieku szkolnym wywodzących się z rodzin rozbitych, http:/ / www.szkolapodstawowa18radom.republika.pl/przyklad11.htm, [dostęp: 03.05.2017].

Walęcka-Matyja K., Zachowania społeczne młodzieży a uwarunkowania rodzinne i osobowościowe, Instytut Psychologii UŁ, http://dspace.uni.lodz.pl/xmlui/bitstream/handle/ 11089/5039/K.Wal\% C4\%99cka-Matyja\%282009\%29.Zachowania\%20spo\% C5\%82eczne $\%$ 20m \% C5\% 82odzie \% C5\% BCy\% 20a \% 20uwarunkowania \%20rodzinne \% 20i \% 20 osobowo\% C5\%9Bciowe.pdf?sequence=1\&isAllowed=y, [dostęp: 01.05.2017].

Więckowski R., Wychowanie przedszkolne podstawowym etapem edukacji, Wychowanie w Przedszkolu, 1994, 9.

Zwierzchowska I., Pozycja społeczna w grupie przedszkolnej dzieci z rodzin niepetnych, Bliżej Przedszkola. Wychowanie i Edukacja, 2007, 3. 